\title{
PROS AND CONS OF CONVERGENCE WITH INTERNATIONAL FINANCIAL REPORTING STANDARDS IN A DEVELOPING COUNTRY: THE PRACTITIONER'S VIEW
}

\author{
Mazni Abdullah and Noor Sharoja Sapiei
}

\begin{abstract}
This study aims to gauge the practitioner's view on convergence with International Financial Reporting Standards (IFRS) in a developing country. Semi-structured interviews with accounting practitioners were conducted to achieve this objective. While the benefits of convergence with IFRS were widely acknowledged among the respondents, they also claimed that IFRS posed a few problems and were disadvantageous to Malaysian companies. The findings from this study could give insights to the International Accounting Standards Board, standard-setters, professional accounting bodies and investors, locally and from abroad who have profiles similar to Malaysia, on how they could improve the process of convergence with IFRS.
\end{abstract}

Keywords IFRS, Convergence, Developing Country, Malaysia

\section{Introduction}

Convergence with the International Financial Reporting Standards (IFRS) has received much attention in academic and professional accounting literature worldwide. Undeniably, it is one of the most significant regulatory changes in accounting history. An increasing demand for a set of international accounting standards is as a result of globalisation and advancements in technology that promote global investment and capital markets (Buchanan, 2003; Rezaee et al., 2010 ). IFRS are accounting standards issued by the International Accounting Standards Board (IASB), and are largely based on the settings of developed economies. Hence, it has always been a concern whether the adoption of the accounting standards of developed-country (i.e. the IFRS) would be useful or relevant to developing countries given the differences in culture and the economic environment between developed and developing countries (Saudagaran and Diga, 1997; Chamisa, 2000; Prather-Kinsey, 2006; Tyrrall et al., 2007). It had been contended that accounting standards had to reflect their environment to provide useful learning (Prather- Kinsey, 2006). The benefits of IFRS might not work in countries with inadequate infrastructure, for example, because such situations

Corresponding author: Dr Mazni Abdullah is a Senior Lecturer at the Department of Accounting, Faculty of Business and Accountancy, University of Malaya, email: mazni@um.edu.my. Co-author: Dr. Noor Sharoja Sapiei is a Senior Lecturer at the Department of Accounting, Faculty of Business and Accountancy, University of Malaya, email:noorsharoja@um.edu.my 
might countervail reporting incentives (Karampinis and Hevas, 2011). Thus, it is likely that accounting standards develop based on advanced economies may not be fully useful or relevant for developing countries (Chamisa, 2000; Tyrrall et al., 2007). The debate on the relevance of IFRS to developing countries is irrelevant if countries pursuing a single set of global accounting standards to enable them to compete globally and to be accepted in the international community. Studies on convergence with international accounting standards, therefore, tended to focus on obstacles and challenges of countries that had adopted or intended to adopt the IFRS (Larson and Street, 2004; Jermakowicz and Gornik-Tomaszewski, 2006; Jones and Higgins, 2006). The findings highlighted by these studies might provide some insights to IASB, national standard-setters, accounting professional bodies and regulators to improve the IFRS and to ensure a smooth process for the implementation or adoption of IFRS in future. Since most studies on convergence with IFRS in the past focused on developed nations, there was now a call for developing countries to provide a wider research base for policy implementation (Joshi et al., 2008). Research in this area was also needed to provide an update on convergence of countries to the IFRS and impediments to its progress (Larson and Street, 2004). This study seeks to contribute to literature on the IFRS by exploring the views of accounting practitioners regarding the pros and cons of convergence with IFRS in a developing country ${ }^{1}$ using semistructured interviews. The main research question is: How do practitioners view the convergence with IFRS in Malaysia? Malaysia is a developing country that vowed to achieve full convergence with IFRS by 1 January 2012. The findings of this study would be of interest to standard-setters, regulators, professional accounting bodies not only at the local level, but also to countries with similar profiles to Malaysia, in dealing with issues of convergence with IFRS. The next section provides background information on IFRS, Malaysia's accounting system and previous studies on IFRS convergence. This is followed by a description of the research methodology and findings from the study. The final section aims to highlight some conclusions.

\section{Literature Review}

\subsection{Research on IFRS}

IFRS are the principle-based standards for financial reporting issued by the International Accounting Standards Board (IASB). Before 2001, the IASB was known as the International Accounting Standards Committee (IASC), and accounting standards issued by the IASC between 1973 and 2000 were recognised as International Accounting Standards (IAS) (Ball, 2006).

1 Developing country is described as a country in the midstream of economic development (Wallace, 1990). 
With the transformation of the IASC into the IASB, the 'harmonisation' mission pursued by the IASC shifted to one of 'convergence' under the IASB (Pacter, 2005). Harmonisation is defined as a "movement away from total diversity of practices" (Tay and Parker, 1990), whereas convergence is the gradual process of narrowing differences between IFRS and the local accounting standards or Generally Accepted Accounting Principles (GAAP) of the country (Ball, 2006). Harmonisation and convergence have both been used in literature to describe efforts by IASB to move towards a single set of global accounting standards, ultimately aiming to reduce international financial reporting diversity to benefit several stakeholders (Jones and Finley, 2010). During the harmonisation mission, developing countries adopted the international accounting standards (IAS) to the extent that they did not conflict with local needs, laws and regulations (Chamisa, 2000). Therefore, countries that adopted IAS under the old regime chose to either modify or not adopt certain standards. The IASB believes that the approach of convergence is better than harmonisation as it could achieve the full adoption of IFRS worldwide. It has been reported that since 2001, almost 120 countries have required or were permitted the use of the IFRS. Under the IFRS regime, the IAS issued by the IASC previously continued to be recognised under the IASB (Ball, 2006).

\subsection{Overview of Malaysia's accounting system}

Malaysia is a developing country and categorised as a common law country as it was under British rule for over 80 years, before it gained independence in 1957. Many aspects of Malaysia's structure, including the social, political and economic systems, have been influenced by the British. Even the Malaysian taxation and accounting systems are based on the British system (Roubi and Richardson, 1998).

Malaysia adopted its first formal financial reporting framework when the Financial Reporting Act 1997 (i.e. FRA 1997) was passed in July 1997 (Susela, 1999). Two bodies were established under the FRA 1997, namely the Financial Reporting Foundation (FRF) and the Malaysian Accounting Standards Board (MASB). The function of the FRF was to oversee the operations, activities and performance of the MASB, whose main function was to issue legally binding accounting standards. Accounting standards issued by the MASB were recognised as approved accounting standards ${ }^{2}$ and adoption of the MASB standards was effective for financial periods commencing on or after 1 July 1999. Under this reporting framework, accounting standards were mandated by law and the enforcement of the standards were entrusted to the three regulatory agencies, namely the Securities Commission (SC), the Central Bank of Malaysia (Bank Negara) and the Companies Commission of Malaysia (CCM). In 2008, Malaysia declared its intention to achieve full convergence with IFRS by 1 January 2012 (MASB, 2008). The Malaysian Accounting Standards Board

2 The approved accounting standards are defined in the FRA 1997 as accounting standards that are issued or adopted by the MASB. 
(MASB) refers to full convergence as full compliance with IFRS. This meant that the Malaysian accounting standards, known as Financial Reporting Standards (FRS), had to be made identical to the IFRS both in terms of its content (i.e. verbatim) and the timing of implementation. Efforts towards convergence had in fact begun in 2005, when the MASB standards were renamed FRS, and the numbering of the standards corresponded to those of IFRS (for example, FRS1 referred to IFRS1, FRS2 referred to IFRS2 and FRS101 referred to IAS1). Since 2006, further streamlining had taken place and standards in the FRS had been made to be identical to the IFRS on a per standard basis. The MASB had continued to adopt the IFRS in stages until the full convergence timeline (MASB, 2008). Subsequent to the full convergence announcement in 2008, the MASB issued a new accounting framework on 19 November 2011, named the Malaysian Financial Reporting Standards (MFRS) framework, which was fully compliant with the IFRS framework. Therefore, as of 1 January 2012, there were three sets of MASB approved accounting frameworks in Malaysia, namely the MFRS framework; the Financial Reporting Standards (FRS) framework; and the Private Entity Reporting Standards (PERS). The MFRS framework applied to all entities other than private entities ${ }^{3}$ except the Transition Entities ${ }^{4}$, beginning on or after 1 January 2012. It has been argued that the convergence path for Malaysia is comparatively easy compared to EU countries or other countries attempting convergence for the first time because the provisions of IAS had been incorporated into local accounting standards since 1978 (Accountants Today, 2008). There had not been much financial impact on transitioning to the MFRS framework (Chan, 2012).

\subsection{Studies on convergence with the IFRS}

Accounting literature has documented several pros and cons of adopting the IFRS in both developed and developing countries. Some advantages highlighted included the reduction or elimination of set-up costs for developing a national accounting system, increases in market efficiency, greater transparency in financial statements, enhancing comparability of financial statements, easing financial reporting requirements for multinational firms, lower cost of capital, facilitating access to capital markets and attracting more foreign investors (Buchanan, 2003; Tyrrall et al., 2007; Tan et al., 2007; Rezaee et al., 2010). The IFRS also allowed small investors to compete better with professional investors because under the IFRS regime, information would become less costly and less risky for small investors (Ball, 2006). Barth et al. (2008)demonstrated that companies

\footnotetext{
3 Private entities are private companies incorporated under the Companies Act 1965 that are not required to prepare and lodge any financial statements under any law administered by Securities Commission (SC) or Bank Negara; and are not subsidiaries or associates or jointly controlled by an entity which is monitored or administered by SC or Bank Negara.

4 Transition entities are entities that fall within the scope of MFRS 141 Agriculture and IC Interpretation 15 Agreements for Construction of Real Estate, including its parent, significant investor and venture. Transition entities have the option either to use MFRS framework or FRS framework as their reporting framework for annual periods beginning on or after 1 January 2012. The Transition entities are required to apply MFRS framework for annual periods beginning on or after 1 January 2017.
} 
that adopted the IFRS exhibited less earnings management, timely loss recognition and more value relevance than companies that did not adopt the IFRS . Similarly, they also found that companies showed an improvement between the pre- and post-IRFS adoption periods. Jones and Finely (2011) examined whether mandatory adoption of the IFRS had resulted in significant reduction in the financial reporting diversity by companies within the EU and Australia. Their results showed statistically significant reductions in the post-IFRS period, and thus provided support for IASB's policy towards global IFRS convergence.

The disadvantages of the IFRS for developing countries were related to the fact that these accounting standards did not fit local needs and institutional structures (Tyrrall et al., 2007). The ability of accounting staff to operationalize international accounting standards in developing countries was also questionable (Perera, 1989). Being principle-based standards, the interpretation in the IFRS was often left to the accounting professions themselves. Hence it was likely that the IFRS would be interpreted and applied inconsistently within and among countries that had adopted it. The aim of a global comparability in financial reports might not be realised if standards in the IFRS were not applied in a uniform and consistent manner (Joshi et al., 2008). There was also the problem of translation of the standards in countries where English was not the dominant language (Perera and Baydoun, 2007). Language problems could result in diversity in interpretation and application of the IFRS (Perera and Baydoun, 2007). Translators with a good knowledge of English and technical accounting concepts were needed to provide the same quality of standards, and people with this expertise were rare (Tan et al., 2007).

In Western countries, a number of studies (such as Larson and Street, 2004; Jermakowicz and Gornik-Tomaszewski, 2006) were carried out to investigate the implementation of the IFRS following the announcement by the European Union (EU) Council of Minister that EU-listed companies were required to prepare consolidated financial statements in accordance with the IFRS beginning on or after 1 January 2005. Larson and Street (2004) examined the progress and perceived impediments to convergence with the IFRS in 17 European countries and based on data compiled by the six largest international accounting firms, found several barriers. The most common barriers were due to underdeveloped capital markets in the country, insufficient guidance on first time application of the IFRS, the tax driven nature of the national accounting regime and the complicated nature of particular standards. Other barriers noted included the lack of experience with certain types of transactions, for example on pensions/ defined benefit plans and financial instruments; the lack of practical knowledge on application of the IFRS, general satisfaction with national accounting standards, the lack of interest from investors and users to change national standards, and the cost of convergence.

Jermakowicz and Gornik-Tomaszewski (2006) carried out a survey in 2004 to examine how publicly-traded companies in Europe implemented the IFRS in their approach to conversion, the impact of IFRS on the financial statements and 
the perceived benefits and challenges of implementing the IFRS. A survey by electronic mail was carried out involving EU-listed companies that had already adopted the IFRS (i.e. early adopters) and those that were in the process of implementing the IFRS. Their findings suggested that the process of implementing the IFRS was costly, complex and burdensome. The majority of companies responded that they would not adopt the IFRS if the standards were not required by the IAS regulation. Other obstacles noted from the survey were: the fair value approach in the measurement of assets/ liability was expected to increase volatility in financial results; complexity of the standards; lack of adequate education and training; lack of knowledge on the IFRS among employees and auditors; and the lack of guidance and uniform interpretation of the IFRS. Other major challenges included constant changes of the IFRS, changing the information technology structure and the mind-set of finance personnel.

Dunne et al. (2008) studied the implementation of the IFRS in three countries, namely the United Kingdom, Italy and Ireland, through carrying out 32 interviews with various stakeholders. Their results showed that the biggest problems in the implementation of IFRS in these countries related to the time and cost spent on training to understand the accounting standards. Some companies even needed major changes in the information systems to accommodate requirements under the IFRS. They also found that the preparers were unsure if the cost of implementation of the IFRS had outweighed the benefits. Interviewees from the United Kingdom and Ireland were more sceptical about IFRS adoption compared to those from Italy. The British and Irish interviewees believed that IFRS adoption would not impact their decision-making regarding investments and they did not expect that the IFRS would be more useful than UK/ Irish GAAP. The interviewees also argued that users of annual reports should be financially literate to understand them because the annual reports produced under the IFRS were too complex.

Jones and Higgins (2006) investigated attitudes and opinions of senior financial executives in top corporations in Australia towards the adoption of the IFRS. A structured telephone survey participated by 60 companies was conducted in late October 2003. They found that the extent of knowledge of the IFRS was greater and the implementation process of the IFRS was more advanced for larger companies compared to smaller ones. Their results also showed that many respondents did not believe that the benefits of adopting the IFRS outweighed the cost of their implementation, arguing that the standards of the IFRS were more complex and less understandable compared toAustralian accounting standards.

In Bahrain, Joshi et al. (2008) examined the perceptions of accounting and auditing professionals relating to the implementation of the IFRS. Their survey showed that greater comparability of financial performance was the highest benefit perceived by respondents. While responses identified challenges and disadvantages such as training and audit quality-control procedures, the 
respondents felt that the adoption of the IFRS would result in benefits at the international level that would outweigh the costs.

In Malaysia, Tan et al. (2007) surveyed the impact of IFRS adoption on Malaysian public-listed companies. They received 67 responses out of 888 questionnaires sent through mail. Their study found that close to three-quarters (71.6\%) of the companies surveyed had fully adopted the FRS from 2006. They found that the biggest drawback in the implementation of the IFRS in Malaysia was the lack of briefing to financial analysts and investors on the impact of the FRS on the companies' financialstatements.

Sidik and Abd Rahim (2012) examined the benefits and challenges of the IFRS from the perspective of accounting practitioners using a questionnaire survey. Their respondents observed that the IFRS brought substantial benefits to business organisations, especially with regards to the investor confidence, because the adoption of the IFRS led to greater transparency and comparability. They documented that high costs was the biggest challenge facing respondents because they needed to pay for staff training, engaging specialists, upgrading their system and bear higher audit fees.

In summary, prior studies using questionnaire surveys identified several obstacles and challenges to convergence with the IFRS such as the complexity of accounting standards, costs involved in convergence efforts, the lack of education and training, and that the IFRS was burdensome. The present study attempts to complement the findings of previous research and contribute to literature by using a semi-structured interview approach to gather the perception of practitioners regarding convergence to standards of the IFRS by a developing country.

\section{Methodology}

Semi-structured interviews were used in this study where an interview guide was used to ensure important issues were covered and that the same basic questions were pursued with interviewees. The questions used were open-ended to allow interviewees to express their views in their own words. Although the questions seem fixed, the interviewer was free to follow up on ideas, probe responses and ask for further elaboration during the interview (Arksey and Knight, 2007). Accounting practitioners for this study referred to individuals who work in accounting-related jobs such as accountants and auditors. They play a pivotal role in the preparation and verification of financial reports; hence they were the most suitable people to be interviewed to get feedback on the impact of the adoption of IFRS. In this study, 23 account preparers ${ }^{5}$ and 11 auditors were interviewed. The interviews were conducted between January and April 2010, and lasted between 60 and 90 minutes for each session. Each interview was recorded and subsequently transcribed for review.

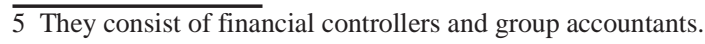


The research protocol was followed to address ethical concerns in interview research. Firstly, we obtained approval from the research unit of university before carrying out the interviews. Secondly, interviewees were informed of the objectives and procedures of the interview. These included their right not to answer specific questions; that anonymity and confidentiality of interviewees and organisations they represented was guaranteed; how information used and quoted in the study would not be traceable; and that the plan was to publish the findings in journals. The assurance of confidentiality might also influence respondents to be more honest in responding to questions (Arksey and Knight, 2007). To guarantee anonymity and confidentiality of interviewees, their name and organisations they represented were not disclosed in this study. Instead they were assigned a number and a letter, for example auditor from firm 1 was assigned A1 and preparer from firm 3 was assignedP3.

While validity and reliability concepts are also important in qualitative research, the approach is different from what has been applied in positivistic studies (Mc Kinnon, 1988). To address validity and reliability issues in interviews, we followed the approaches suggested by Mc Kinnon (1988). Firstly, managing the interpersonal behaviour of the researchers, where they should be seen as nonthreatening, confident, respectful of the interviewees, trustworthy and genuinely interested in the subject. Secondly, the researchers took notes during the interview process not only to serve as supporting documentation, but also because it could minimize bias in the interpretation of results. Thirdly, the researchers probed the questions in the interview so that issues could be clarified, thus avoiding the need for them to make their own speculations aboutfindings.

\section{Findings}

\subsection{Advantages of the IFRS to Malaysia}

The majority of interviewees expressed the view that convergence with the IFRS would benefit Malaysian companies in terms of the opportunity to compete globally and to reassure international investors. Investors would have more confidence and trust if financial statements were prepared in compliance with the IFRS compared to if statements were prepared according to local standards. Some of the remarks on convergence with the IFRS were:

"It is a good move to converge with IFRS because businesses today operate beyond their domestic markets... the [IFRS] adoption not only assures the confidence of investors but also enhances our capital market."(A2)

"By having IFRS-compliance, we increase investor confidence towards Malaysian companies; our financial reports are of the same standards or quality with those prepared by the UK or European companies... and this will facilitate our companies to access international financial markets." (P7) 
Other advantages highlighted by interviewees included:

- From an audit perspective, the standardization of accounting treatments would allow comparability and harmonisation of auditing procedures and practices. This would facilitate global audit sharing that could reduce risk and cause reliable and comparable audit opinions on financial statements.

- Convergence with the IFRS could reduce the workload of account preparers from multinational firms in reconciling or consolidating financial statements prepared using different accounting standards.

- It facilitates better decision-making for international investments as financial statements are comparable and transparent.

Overall, the advantages of convergence with the IFRS highlighted by interviewees in this study were similar to those raised in accounting literature. This showed that the benefits of the IFRS were widely acknowledged among accounting practitioners in Malaysia.

\subsection{Disadvantages of IFRS to Malaysia}

While acknowledging advantages of convergence with the IFRS, the interviewees also contended that the IFRS were disadvantageous to Malaysian companies. Adoption of the IFRS had increased the complexity of audit engagements due to complications associated with certain standards, such as fair value accounting. The issue of fair value accounting and additional disclosure required by the IFRS involved greater complexity in the work scope for auditing. The lack of competency of preparers and auditors in Malaysia to properly interpret standards would also result in additional time and cost to the company, in terms of training and employing experts.

The interviewees also raised concerns regarding the quality of financial statements prepared under the IFRS since they were related to the level of knowledge of preparers and auditors. It was questionable, they said, whether practitioners in Malaysia had the required knowledge and skills because they needed to keep abreast with the latest changes to be compliant to the IFRS, and this would certainly result in additional time and cost to the company.

Some interviewees did not agree with full convergence with the IFRS. They argued that the undeveloped capital market in Malaysia was not suitable for the fair value model standards, such as the MFRS 139 Financial Instruments (IAS 39) and the MFRS 141 Agriculture (IAS 41) ${ }^{6}$ because the referenced market value was not readily available. Thus, it could be costly for Malaysian companies to comply with the IFRS requirements. Under the MFRS 141, biological assets (such as oil palm trees) had to be displayed in the financial statements at their fair value.

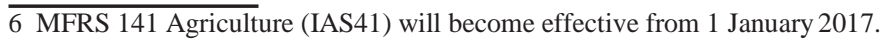


They also argued that certain standards in the IFRS were not relevant to Malaysia because the way in which Malaysian companies conducted their business differed from Europe countries and others. For example, the new interpretation issued by the International Financial Reporting Interpretations Committee on real estate sales (namely IFRIC 15 or IC Interpretation 15 in Malaysia) ${ }^{7}$ would put pressure on Malaysian property developers. This was because the IFRIC15 required property developers to recognise revenue on a completed basis ${ }^{8}$, which was opposed to current practices of being on a percentage basis. In this regard, interviewees were of the view that Malaysia should only adopt standards within the IFRS that were relevant to national needs. Some of their responses were:

"With the growing globalizing trend, increasing the FDI (foreign direct investment)...leaves us with no choice...we must converge with IFRS. But, IFRS especially FRS139 requires fair value. It may not be a hundred per cent suitable for us in Asia. Those requirements may be suitable in Europe or UK because the fair value is quite easily determine by them...they have the market, the market is liquid, but here...like for unquoted shares, you don't have a market value. Even for certain derivatives, if the market is not active you have to make your judgment. To apply this in practice is tough..."(A6)

"Regarding IFRS convergence, I would say 'yes' and 'no'. Yes, we should converge to IFRS because we have to move with the world to adopt the international standards. No because not all business models are the same... the way we conduct our business is different from Europe, US or India. If we have to adopt IFRC15 on property development, for example, we have to incur additional costs because we need to prepare two sets of accounts. One on the percentage of completion method for income tax purposes and the other on the completed basis method...sad to say, the IRB has not done anything about this yet." (P18)

The findings above might support arguments that the accounting standards of Western countries were irrelevant to developing countries due to different environmental factors, such as an undeveloped capital market and less sophisticated technology and user knowledge (Perera, 1989; Chamisa, 2000). According to Briston (1978), developing countries should create a system that was suitable to their own needs rather than adopt Western systems. Nevertheless, to have accounting standards specially tailored to the needs of the Malaysian environment does not seem possible since many countries worldwide have adopted a single set of international accounting standards (i.e. the IFRS).

7 IFRIC 15 will be replaced with IFRS 15 and will become effective from 1 January 2017.

8 Property developers in Malaysia have been using a local standard, i.e. FRS201-Property Development Activities, since the 1980s, and revenue from property development activities is recognized based on the stage of completion (Zain, 2010). 
Furthermore, Malaysia would not get recognition as an IFRS-compliant country if standards were modified to suit local needs or requirements.

Interestingly, while previous studies argued that the English language was a barrier for convergence and highlighted the importance of translating the IFRS into different languages (Abd-Elsalam and Weetman, 2003; Aljifri and Khasharmeh, 2006), the majority of respondents did not view translation of the IFRS into national languages as necessary. This was because English was widely used as a language for business in Malaysia.

\section{Conclusion}

This study gathered the views of accounting practitioners regarding the convergence with the IFRS in Malaysia via semi-structured interviews. It highlighted advantages and disadvantages of the IFRS from the perspective of practitioners. The interviews suggested that although full convergence with the IFRS benefitted Malaysian companies, it also created problems and challenges for companies to comply with the IFRS. Firstly, there was increased complexity in the work scope for auditing due to the difficulty of certain accounting standards. Secondly, it involved higher costs and more time to train the accounting staff and to employ experts. Thirdly, the quality of financial reports was questionable because it also related to the knowledge and skills of preparers and auditors. Fourthly, an undeveloped capital market did not facilitate compliance with fair value accounting standards as it contributed to high compliance costs. Finally, different business models or practices also made it costly for property developers to comply fully with the IFRS because it was highly likely that companies would prepare two sets of accounts - one for taxation purposes and the other for financial reporting purposes. Furthermore, the lack of support from the Inland Revenue Board (IRB) also discouraged Malaysian companies from complying with the IFRS in Malaysia (Zain, 2010). It was reported that the IRB did not familiarise itself with the IFRS, nor did it take part in any discussion with accounting professionals to solve problems in taxation. Overall, this study found that respondents had confidence in the IFRS, but there were also national implementations issues that needed to be considered and tackled by the authorities such as the MASB to ensure full adoption of the IFRS in Malaysia.

The IFRS has become prevalent worldwide and the tendency for countries to adopt the IFRS has been accelerating in recent years. These findings can give some insights to the IASB, standard-setters, professional accounting bodies and investors both locally and from countries with similar profiles to Malaysia, on how to improve the process of convergence with the IFRS. 


\section{References}

Abd-Elsalam, O.H. and Weetman, P. (2003). Introducing International Accounting Standards to an emerging capital market: Relative familiarity and language effect in Egypt. Journal of International Accounting, Auditing and Taxation, 12, 63-84.

Accountants Today (2008). Full Convergence with IFRS in 2012. October issue, 22-23. KL: MIA.

Aljifri, K. and Khasharmeh, H. (2006). An investigation into the suitability of the international accounting standards to the United Arab Emirates environment. International Business Review, 15, 505-526.

Arksey, H. and Knight, P. (2007). Interviewing for Social Scientists. London: SAGE

Ball, R. (2006). International Financial Reporting Standards (IFRS): pros and cons for investors. Accounting and Business Research, 36, 5-27.

Barth, M. E., Landsman, W. R. and Lang, M. H. (2008). International Accounting Standards and Accounting Quality. Journal of Accounting Research, 46(3), 467-498.

Briston, R. J. (1978). The evolution of accounting in developing countries. International Journal of Accounting, 14(1), 105-120.

Buchanan, F. R. (2003). International accounting harmonisation: Developing a single world standard. Business Horizons, May-June, 61-70.

Chamisa, Edward E. (2000). The relevance and observance of the IASC standards in developing countries and the particular case of Zimbabwe. The International Journal of Accounting, 35 (2), 267-286.

Chan, James (2012). How is the progress on IFRS convergence in Malaysia now? July E- newsletter, www.crowehorwarth.com.my. Accessed date: 30/10/2012.

Dunne, T., Fifield, S., Finningham, G., Fox, A., Hannah, G., Helliar, C., Power, D., and Veneziani, M. (2008). The implementation of IFRS in the UK, Italy and Ireland. Edinburgh: ICAS.

Jermakowicz, E.K. and Gornik-Tomaszewski, S. (2006). Implementing IFRS from the perspective of EU publicly traded companies. Journal of International Accounting,Auditing and Taxation, 15, 170-196.

Jones, S. and Finley, A. (2011). Have IFRS made a difference to intra-country financial reporting diversity? The British Accounting Review, 43, 22-38.

Jones, S. and Higgins, A. D. (2006). Australia's switch to international financial reporting standards: a perspective from account preparers. Accounting and Finance, 46, 629-652.

Joshi, P.L., Bremser, W.G. and Al-Ajmi, J. (2008). Perceptions of accounting professionals in the adoption and implementation of a single set of global accounting standards: Evidence from Bahrain. Advances in Accounting, 24, 41-48.

Karampinis, N. I. and Hevas, D. L. (2011). Mandating IFRS in an unfavourable environment: The Greek Experience, The International Journal Accounting, 46, 304-332. 
Larson, R.K. and Street, D., (2004). Convergence with IFRS in an expanding Europe: progress and obstacles identified by large accounting firms' survey. Journal of International Accounting, Auditing and Taxation, 13, 89-119.

MASB (2008). Malaysia's Convergence with IFRS in 2012. Accessed via www.masb.org.my. Accessed date: 06/09/2009.

McKinnon, J. (1988). Reliability and Validity in Field Research: Some Strategies and Tactics. Accounting, Auditing and Accountability Journal, 1(1), 34-54.

Pacter, P. (2005). What exactly is convergence? Int. J. Accounting, Auditing and Performance Evaluation, 2, 67-83.

Perera, H. and Baydoun, N. (2007). Convergence with International Financial Reporting Standards: The case of Indonesia. Advances in International Accounting, 20, 201-224.

Perera, M. H. B. (1989). Accounting in developing countries: A case for localized uniformity. British Accounting Review, 21, 141-158.

Prather-Kinsey, J. (2006). Developing countries converging with developedcountry accounting standards: Evidence from South Africa and Mexico. The International Journal of Accounting, 41, 141-162

Rezaee, Z., Smith, L.M., and Szendi, J.Z. (2010). Convergence in accounting standards: Insights from academicians and practitioners. Advances in Accounting, incorporating Advances in International Accounting, 26, 142154.

Roubi, R. R. and Richardson, A. W. (1998). Managing Discretionary Accruals in Response to Reductions in Corporate Tax Rates in Canada, Malaysia and Singapore.International Journal of Accounting, 33(4), 455-467.

Saudagaran, S. M. and Diga, J. G. (2000). The International Environment of Financial Reporting Regulation in ASEAN. International Journal of Accounting, 35(1), 1-26.

Sidik, M. H. J. and Abd Rahim, R. (2012). The benefits and challenges of Financial Reporting Standards in Malaysia: Accounting practitioners' perceptions. Australian Journal of Basic and Applied Sciences, 6(7), 98-108.

Susela, S. D. (1999) "Interest" and accounting standard setting in Malaysia. Accounting, Auditing and Accountability Journal, 12(3), 358- 387.

Tan, L.L., Lazar, J. and Othman, R. (2007). Adoption of Financial Reporting Standards (FRS): Impact on Malaysian companies. Working paper, Malaysian Accounting Research and Education Foundation (MAREF).

Tay, J.S.W. and Parker, R.H. (1990). Measuring International Harmonization and Standardization. ABACUS, 26(1), 71-88.

Tyrrall, D., Woodward, D, and Rakhimbekova, A. (2007). The relevance of International Financial Reporting Standards to a developing country: Evidence from Kazakhstan. The International Journal of Accounting, 42, 82110.

Zain, N. (2010). New Era of Financial Reporting for Developers- Impending adoption of real estate accounting standards will radically change revenue figures of property development companies. Available from: www.delloite.com. Accessed date: 29/9/2010 